\title{
KARAKTERISTIK BRIKET LIMBAH TONGKOL JAGUNG DENGAN PEREKAT TEPUNG BIJI NANGKA SEBAGAI BAHAN BAKAR ALTERNATIF
}

\author{
Ibrahim Hasan'), Abdul Ghofur2) \\ 1,2Program Studi Teknik Mesin \\ Fakultas Teknik Universitas Lambung Mangkurat \\ JL. Akhmad Yani Km.36 Banjarbaru, Kalimantan Selatan,70714 \\ Telp. 0511-4772646, Fax 0511-4772646 \\ E-mail : ibrahimhsn96@gmail.com
}

\begin{abstract}
Briquette is one of the alternative energy sources as a satisfactory substitute for fossil fuels in which the availability decreases every single day. The main materials of briquettes can be biomass. Biomass is an organic material produced by photosynthetic process, the materials may be product, remnant or waste. One of the potentially great biomass to be used as the main ingredient of briquettes is corncob. This study aims to (1) know the characteristics of corncob briquettes with adhesive jackfruit seed flour including moisture content, ash content, volatile matter and calorific value, (2) know the characteristics of the best corncob briquettes based on SNI standard. Corn cobs were converted first to charcoal with carbonization process, and then the charcoal was mixed with adhesive derived from jackfruit seed flour. In this study, variations of corncob to jackfruit seeds ratios were $90 \%: 10 \%, 85 \%: 15 \%$ and $80 \%: 20 \%$, respectively. Then a mixture of charcoal and flour was molded with a molding pressure variation of $100 \mathrm{~kg} / \mathrm{cm} 2$ and $120 \mathrm{~kg} / \mathrm{cm} 2$. The parameters of briquette characteristics based on SNI 01-6235-2000 are moisture content, ash content, volatile matter and calorific value. The results show that the best characteristic briquettes is briquettes with sample code of B1 with charcoal to jackfruit flour ratio of $90 \%$ to $10 \%$ and printing pressure of $120 \mathrm{~kg} / \mathrm{cm} 2$. The briquettes have water content characteristics of $7,0073 \%$, ash content of $6,8876 \%$, volatile matter of $17,8983 \%$ and calorific value of $6241,8137 \mathrm{cal} / \mathrm{gram}$. But overall, the briquettes have not met the SNI 01-6235-2000 standards because the level of volatile matter in the briquettes exceed the maximum limit that has been determined i.e. $15 \%$.
\end{abstract}

Keywords: briquette, corncob, jackfruit seeds, biomass, composition, pressure.

\section{PENDAHULUAN}

Energi merupakan salah satu hal yang sangat penting di dunia. Ada berbagai macam sumber energi di dunia pada saat ini. Diantaranya adalah energi surya atau matahari, energi panas bumi, energi angin, energi biomassa, energi gas alam dan energi fosil. Setiap tahun keperluan akan energi terus semakin meningkat. Hal ini dikarenakan semakin meningkatnya aktivitas manusia yang menggunakan bahan bakar terutama bahan bakar minyak yang bersumber dari fosil tumbuhan maupun hewan.

Pada tahun 2006, penggunaan energi fosil di Indonesia yaitu tercatat $52,2 \%$ minyak bumi, $21,5 \%$ batubara, $19 \%$ gas bumi, air 3,7\%, panas bumi $3 \%$ dan energi yang dapat diperbaharui $0,2 \%$ (Ahmad Syaiful, 2010). Energi fosil masih sangat mendominasi kebutuhan energi di Indonesia, permasalahannya adalah energi fosil 
merupakan energi yang tidak dapat diperbaharui artinya energi tersebut suatu saat akan habis, sehingga diperlukan energi alternatif sebagai pengganti yaitu energi yang dapat diperbaharui.

Salah satu energi terbarukan yang memiliki potensi besar yaitu energi biomassa. Biomassa merupakan bahan organik hasil fotosintetik, baik berupa produk maupun sisa atau limbah (Gregory, 1977 dalam Widarto). Biomassa yang berasal dari limbah pertanian biasanya dianggap sebagai bahan yang sudah tidak berguna dan tidak memiliki nilai ekonomis bahkan limbah-limbah tersebut sering berakhir ditempat pembuangan sampah maupun dibakar, padaal limbah-limbah tersebut memiliki potensi untuk diolah menjadi sesuatu yang bernilai ekonomis salah satunya menjadi bahan bakar alternatif.

Salah satu sumber energi biomassa yang berpotensi untuk dijadikan energi terbarukan adalah tongkol jagung. Dari $100 \%$ berat total jagung, 30\% nya adalah tongkol jagung, sedangkan sisanya adalah kulit dan bijinya (Koswara, 1991). Pada tahun 2015 produksi jagung di Indonesia adalah 19.612.435 ton artinya ada sekitar 5.883.730 ton tongkol jagung yang dihasilkan. Umumnya limbah tongkol jagung belum dimanfaatkan oleh masyarakat, biasanya tongkol jagung hanya dibakar atau dibuang begitu saja. Tentu saja hal ini bisa menyebabkan pencemaran lingkungan. Tongkol jagung memiliki nilai HHV yang cukup tinggi yaitu berkisar 14,7-18,9 MJ/Kg (Lachke, 2002) sehingga akan menghasilkan panas yang cukup baik apabila dibakar. Karena itu tongkol jagung memiliki potensi untuk dijadikan bahan bakar alternatif yaitu dikonversikan menjadi briket.

Briket adalah produk pembriketan yang melalui proses pencetakan partikelpartikel padatan pada tekanan tertentu baik dengan atau tanpa bahan perekat maupun bahan tambah lainnya. Sebagai salah satu bentuk bahan bakar alternatif, briket merupakan bahan yang sederhana baik dalam proses pembuatan ataupun dari segi bahan baku yang digunakan sehingga bahan bakar briket memiliki potensi yang cukup besar untuk dikembangkan.

Briket dengan kualitas baik diantaranya memiliki sifat seperti tekstur yang halus, tidak mudah pecah, keras, aman bagi manusia dan lingkungan serta memiliki sifat-sifat penyalaan yang baik. Sifat penyalaan ini diantaranya adalah mudah menyala, waktu nyala cukup lama, tidak menimbulkan jelaga, asap sedikit dan cepat hilang serta nilai kalor yang cukup tinggi.

Beberapa jenis briket yang biasa diproduksi antara lain:

1. Jenis berkarbonasi

Jenis ini terlebih dahulu mengalami proses karbonasi/pengarangan sebelum menjadi briket. Karbonisasi adalah proses pembakaran tidak sempurna dari bahanbahan organik dengan oksigen yang terbatas atau tanpa oksigen. Pada saat proses zat-zat yang mudah terbakar seperti $\mathrm{CO}, \mathrm{CH}_{4}, \mathrm{H}_{2}$, formaldehid, methana, formik dan acetil acid dan juga zat yang tidak terbakar seperti $\mathrm{CO}_{2}, \mathrm{H}_{2} \mathrm{O}$ dan tar cair. Gas-gas yang dilepaskan tersebut memiliki nilai kalor yang tinggi sehingga dapat memenuhi kebutuhan kalor pada saat proses karbonisasi (Singh dkk, 2005). Dengan proses karbonisasi zat-zat terbang yang terkandung di dalam bahan dasar briket tersebut juga dapat diturunkan serendah mungkin sehingga produk akhirnya tidak berbau dan berasap.

2. Jenis nonkarbonisasi

Jenis ini tidak mengalami karbonisasi sebelum diproses menjadi briket dan harganya lebih murah. Karena zat terbang masih terkandung di dalam bahan dasar 
briket maka pada penggunaannya lebih baik menggunakan tungku (bukan kompor), sehingga akan menghasilkan pembakaran yang sempurna dimana seluruh zat terbang yang muncul dari briket akan habis terbakar oleh lidah api dipermukaan tungku.

Perekat pada proses pembriketan berfungsi untuk merekatkan partikel-partikel bahan baku briket, sehingga dihasilkan briket yang kompak. Penggunaan perekat akan mengakibatkan ikatan antar butir-butir briket semakin kuat.

Salah satu bahan yang umum digunakan sebagai perekat yaitu bahan perekat pati, dimana jenis-jenis pati tersebut antara lain pati jagung, kentang, tapioka, beras, sorgum, ubi jalar, sagu, dan lain-lain. Penggunaan perekat pati memiliki beberapa keuntungan yaitu harga murah, mudah pemakaiannya, dapat menghasilkan kekuatan kering yang tinggi, namun perekat ini memiliki kelamahan yaitu ketahanan terhadap air rendah, hal ini disebabkan karena perekat pati mempunyai sifat dapat menyerap air dari udara, sehingga memungkinkan mudah diserang jamur, bakteri, dan binatang pemakan pati. Secara umum perekat yang baik, yaitu mempunyai bau yang baik bila dibakar, kemampuan merekat yang baik, harga yang murah, dan mudah didapat. Pada penelitian ini perekat yang digunakan adalah tepung biji nangka, hal ini dikarenakan pada penelitian Ellyta Sari, dkk (2015) briket yang menggunakan perekat berbahan tepung biji nangka memiliki karakteristik yang sedikit lebih baik dibandingkan briket yang menggunakan perekat berbahan tapioka yaitu kadar air yang lebih rendah, kadar abu yang lebih rendah dan nilai kalor yang lebih tinggi.

Karakteristik briket yang terdapat pada penelitian ini yaitu, (1) Kadar air, kadar air briket merupakan perbandingan berat air yang terdapat pada briket tersebut dengan berat kering pada briket tersebut. (2) Kadar abu, kadar abu merupakan zat anorganik yang tertinggal apabila briket dibakar secara sempurna. (3) Volatile matter, volatile matter atau yang sering disebut dengan zat mudah menguap memepengaruhi pembakaran briket. Kandungan volatile matter mempengaruhi kesempurnaan pembakaran dan intensitas api. (4) Nilai kalor, nilai kalor adalah jumlah panas yang dihasilkan briket per satuan bobot bahan yang mudah terbakar pada saat pembakaran sempurna (Syachri, 1983).

\section{METODE PENELITIAN Alat dan Bahan}

Alat dan bahan yang digunakan pada penelitian ini antara lain adalah: tongkol jagung, biji nangka, air, sieve sacker, timbangan, alat pencetak briket, kompor, kaleng bekas, lumpang dan alu, gelas plastik, kayu pengaduk dan oven listrik.

\section{Prosedur Penelitian \\ Pengolahan Bahan}

Langkah pengolahan bahan dalam penelitian ini, antara lain:

a. Tongkol jagung yang sudah dikumpulkan dibersihkan, kemudian dipotong menjadi kecil setelah itu dijemur di bawah sinar matahari hingga bahan terlihat kering.

b. Biji nangka yang sudah dikumpulkan dibersihkan, lalu direbus selama kurang lebih 1 jam. Setelah itu biji nangka ditumbuk hingga halus, kemudian dijemur di bawah sinar matahari hingga kering. Tumbuk kembali biji nangka agar halus. 


\section{Pengarangan Tongkol Jagung}

Tongkol jagung yang telah kering dimasukkan ke dalam kaleng, setelah itu kaleng dipanaskan menggunakan kompor selama 60 menit.

\section{Penghalusan Ukuran Partikel Arang}

Penghalusan ukuran partikel arang dilakukan dengan cara ditumbuk secara manual menggunakan lumpang dan alu.

\section{Penyaringan}

Penyaringan arang tongkol jagung dilakukan dengan menggunakan alat sieve sacker dengan ukuran partikel lolos 40 mesh. Jika terdapat arang yang tidak lolos maka akan dilakukan penghalusan kembali.

Penyaringan tepung biji nangka dilakukan menggunakan alat sieve sacker dengan ukuran partikel lolos 60 mesh.

\section{Pencetakan}

Pada penelitian ini dilakukan variasi yaitu pada komposisi arang dengan tepung dan tekanan penetakan. Variasi penelitian ditampilkan pada Tabel 1.

Tabel 1. Variasi penelitian

\begin{tabular}{|c|c|c|c|}
\hline $\begin{array}{c}\text { Kode } \\
\text { Sampel }\end{array}$ & $\begin{array}{c}\text { Tongkol } \\
\text { Jagung } \\
(\%)\end{array}$ & $\begin{array}{c}\text { Tepung Biji } \\
\text { Nangka } \\
(\%)\end{array}$ & $\begin{array}{c}\text { Tekanan } \\
\left(\mathrm{Kg} / \mathrm{cm}^{2}\right)\end{array}$ \\
\hline A1 & 90 & 10 & 100 \\
\hline A2 & 85 & 15 & 100 \\
\hline A3 & 80 & 20 & 100 \\
\hline B1 & 90 & 10 & 120 \\
\hline B2 & 85 & 15 & 120 \\
\hline B3 & 80 & 20 & 120 \\
\hline
\end{tabular}

Panaskan air hingga mendidih kemudian masukkan tepung biji nangka lalu aduk adonan perekat hingga mengental. Selanjutnya campurkan adonan perekat dengan arang tongkol jagung aduk hingga merata. Setelah itu campuran arang dan perekat dimasukkan ke dalam cetakan berbentuk silinder setelah itu ditekan dengan alat hidrolik.

\section{Pengeringan}

Proses pengeringan brike dilakukan menggunakan oven listrik dengan temperatur $90^{\circ} \mathrm{C}$ selama 120 menit.

\section{PEMBAHASAN}

Dari hasil penelitian yang telah dilakukan diperoleh nilai kadar air, kadar abu, kadar volatile matter dan nilai kalor briket limbah tongkol jagung yang dicantumkan dalam Tabel 2. 
Tabel 2. Hasil pengujian

\begin{tabular}{|c|c|c|c|c|}
\hline \multirow[b]{2}{*}{$\begin{array}{l}\text { Kode } \\
\text { Sampel }\end{array}$} & \multicolumn{4}{|c|}{ Hasil Pengujian } \\
\hline & $\begin{array}{l}\text { Kadar Air } \\
(\%)\end{array}$ & $\begin{array}{l}\text { Kadar } \\
\text { Abu (\%) }\end{array}$ & $\begin{array}{c}\text { Kadar Volatile } \\
\text { Matter }(\%)\end{array}$ & Nilai Kalor \\
\hline A1 & 7,6643 & 6,6538 & 18,1494 & 6126,4027 \\
\hline A2 & 9,8159 & 6,4323 & 18,7370 & 5898,4232 \\
\hline A3 & 12,0595 & 6,2405 & 20,3581 & 5772,5275 \\
\hline B1 & 7,0073 & 6,8876 & 17,8983 & 6241,8137 \\
\hline B2 & 9,1915 & 6,7317 & 18,4807 & 5951,8225 \\
\hline B3 & 11,5085 & 6,4933 & 20,2564 & 5846,2300 \\
\hline
\end{tabular}

\section{Pengujian Kadar Air}

Hasil pengujian kadar air ditampilkan pada Gambar 1.

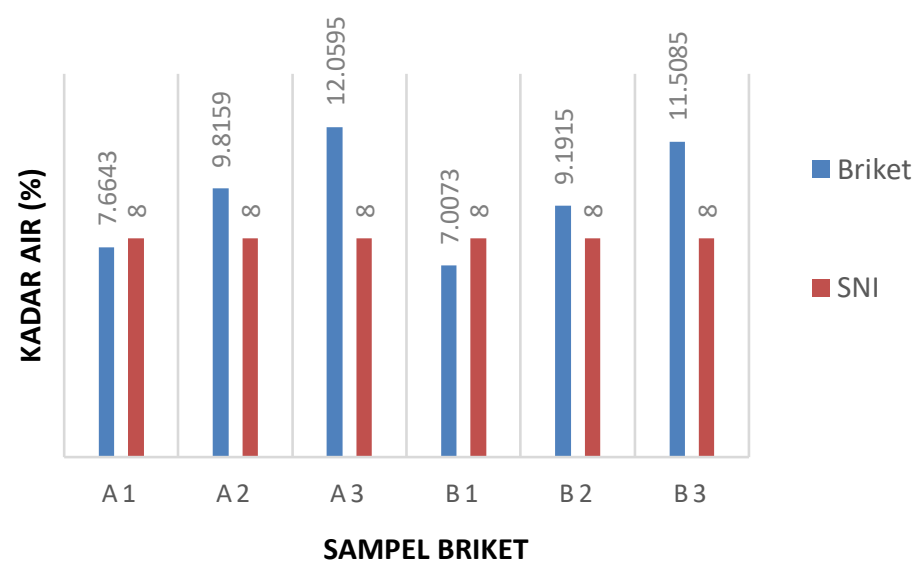

Gambar 1. Grafik Kadar Air

Berdasarkan Gambar 1, briket dengan kode sampel A1 memiliki kadar air sebesar 7,6643\%, A2 memiliki kadar air sebesar 9,8159\%, A3 memiliki kadar air sebesar 12,0595\%, B1 memiliki kadar air sebesar 7,0073\%, B2 memiliki kadar air sebesar 9,1915, dan B3 sebesar 11,5085. Dari keenam briket tersebut hanya dua yang memenuhi standar nilai kadar air SNI 01-6235-2000 tentang mutu briket arang kayu dengan kadar air maksimal $8 \%$ yaitu briket $\mathrm{A} 1$ dengan nilai kadar air sebesar $7,6643 \%$ dan $\mathrm{B} 1$ sebesar $7,0073 \%$.

Pada grafik memperlihatkan semakin banyak perekat maka kadar air yang ada pada briket semakin besar. Hal ini dikarenakan semakin banyak komposisi tepung pada campuran arang dan tepung maka air yang diperlukan untuk mengentalkan tepung semakin banyak. Hasil penelitian ini sesuai dengan penelitian Aquino Ghandi (2009) yang melakukan penelitian pembuatan briket dengan variasi kadar perekat, dari hasil penelitiannya semakin banyak kadar perekat yang digunakan maka kadar air briket akan semakin tinggi.

Pada grafik memperlihatkan semakin besar tekanan pencetakan briket maka kadar air semakin mengecil. Hasil penelitian ini sesuai dengan penelitian Moch. Yunus (2015) yang melakukan penelitian pembuatan briket dengan variasi tekanan pencetakan dari hasil penelitiannya semakin besar tekanan pencetakan briket maka 
kadar air akan semakin kecil. Menurutnya hal ini disebabkan pada saat pencetakan, air akan terbuang keluar dalam jumlah tertentu.

Briket yang memiliki kadar air tinggi disebabkan karena kurang optimalnya proses pengeringan. Semakin lama proses pengeringan maka kadar air pada briket akan semakin menurun. Selain itu, kadar air akan mempengaruhi nilai kalor yang dihasilkan. Tingginya kadar air akan menyebabkan penurunan nilai kalor (Hendra dan Darmawan, 2000).

\section{Pengujian Kadar Abu}

Hasil pengujian kadar abu ditampilkan pada Gambar 2.

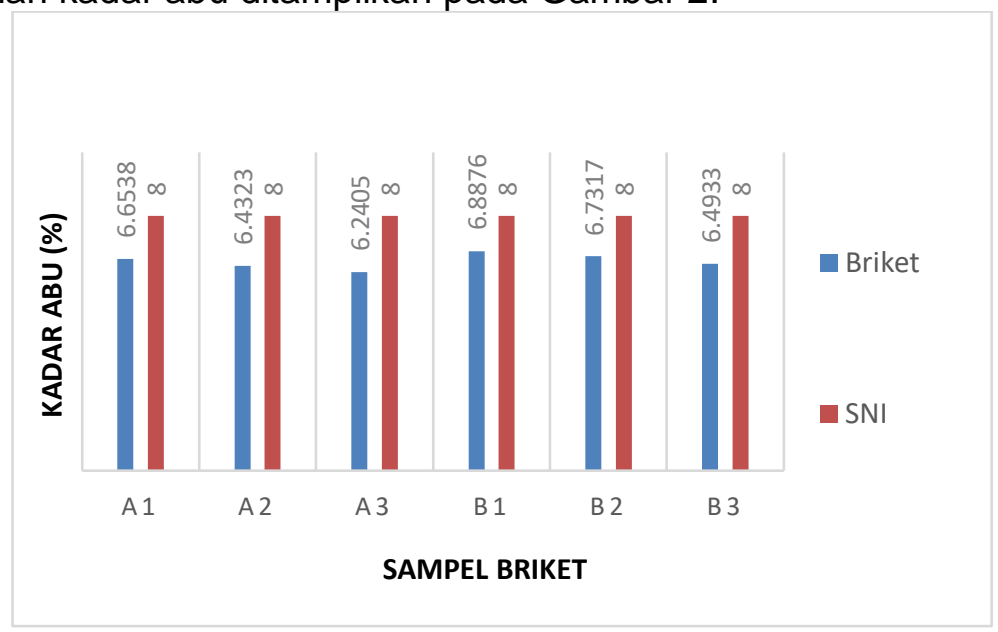

Gambar 2. Grafik kadar abu

Berdasarkan Tabel 2 dan Gambar 2, briket dengan kode sampel A1 memiliki kadar abu sebesar 6,8876\%, A2 memiliki kadar abu sebesar 6,7317\%, A3 memiliki kadar air sebesar 6,4933\%, B1 memiliki kadar abu sebesar 6,6538\%, B2 memiliki kadar abu sebesar 6,4323\%, dan B3 memiliki kadar abu sebesar 6,2405\%. Hasil menunjukkan kadar abu pada briket satu sama lain tidak terlalu jauh berbeda.

Briket dengan kadar abu terendah yaitu briket B3 dengan kadar abu sebesar $6,2405 \%$ dan briket dengan kadar abu tertinggi yaitu briket A1 dengan kadar abu sebesar $6,8876 \%$. Dari keenam briket tesebut semuanya telah memenuhi standar nilai kadar abu SNI 01-6235-2000 tentang mutu briket arang kayu dengan kadar abu maksimal 8\%.

Pada grafik memperlihatkan semakin banyak komposisi perekat maka kadar abu semakin rendah. Hasil ini sesuai dengan penelitian A'yan Sabitah (2015) pada penelitian tersebut dilakukan variasi kadar perekat, hasil dari penelitian tersebut menunjukkan semakin banyaknya kadar perekat maka kadar abu akan semakin menurun. Kadar abu dipengaruhi oleh kandungan bahan - bahan yang terdapat dalam perekat maupun arang seperti silika (Maryono, 2013).

Pada grafik memperlihatkan semakin besar tekanan pencetakan briket maka kadar abu semakin rendah. Hasil ini sesuai dengan penelitian Moch. Yunus (2015) pada penelitian tersebut dilakukan variasi tekanan pencetaan briket, dari hasil penelitian menunjukkan semakin besar tekanan pencetakan briket maka kadar abu pada briket semakin rendah. Hal ini disebabkan briket yang dicetak dengan tekanan lebih tinggi memiliki kadar air yang lebih rendah sehingga akan memungkinkan 
terbakar lebih sempurna ketika dilakukan pembakaran dan menghasilkan abu yang lebih sedikit.

\section{Pengujian Kadar Volatile Matter}

Hasil pengujian kadar volatile matter ditampilkan pada pada Gambar 3.

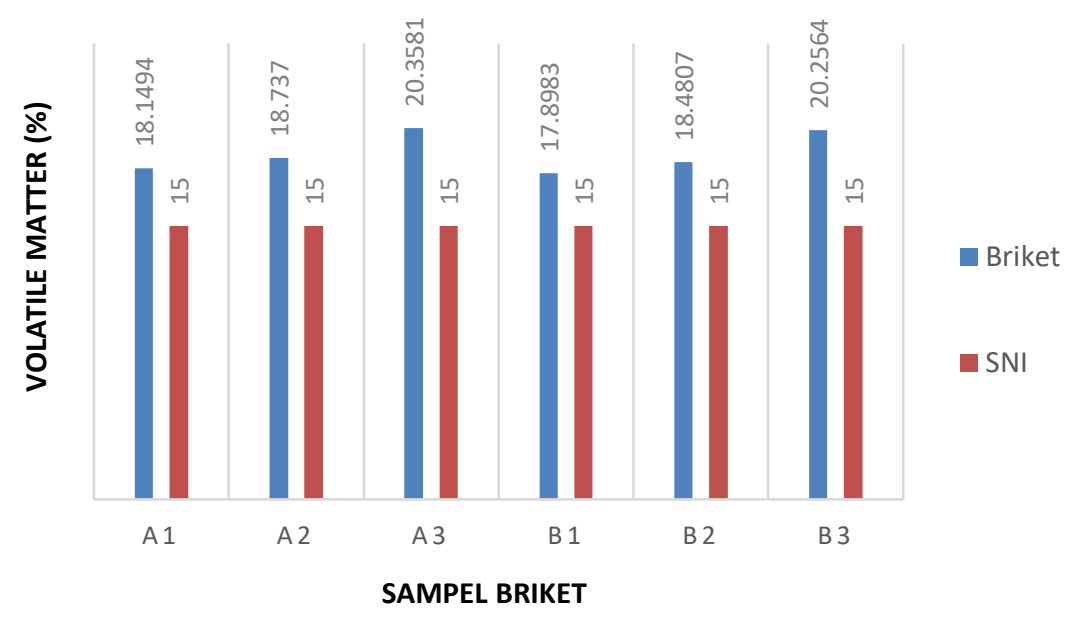

\section{Gambar 3. Grafik Kadar Volatile Matter}

Berdasarkan Tabel 2 dan Gambar 3, briket dengan kode sampel A1 memiliki kadar volatile matter sebesar 18,1494, A2 memiliki kadar volatile matter sebesar 18,737\%, A3 memiliki kadar volatile matter sebesar 20,3581\%, B1 memiliki kadar volatile matter sebesar $17,8983 \%$, B2 memiliki kadar volatile matter sebesar $18,4807 \%$, dan B3 memiliki kadar volatile matter sebesar $20,2564 \%$.

Briket dengan kadar volatile matter terendah yaitu pada briket B1 yang memiliki kadar volatile matter sebesar $17,8983 \%$ dan briket dengan kadar volatile matter tertinggi yaitu briket A3 yang memiliki kadar volatile matter sebesar $20,3581 \%$. Artinya semua briket belum ada yang memenuhi standar nilai kadar volatile matter SNI 01-6235-2000 tentang mutu briket arang kayu dengan kadar volatile matter maksimal $15 \%$.

Pada grafik memperlihatkan semakin banyak komposisi perekat maka kadar volatile matter semakin tinggi. Hasil ini sesuai dengan penelitian Muhammad Faizal, dkk (2014) pada penelitian tersebut dilakukan variasi kadar perekat, dari hasil penelitian menunjukkan semakin banyak kadar perekat maka akan semakin tinggi kadar volatile matter. Hal ini mungkin disebabkan karena besarnya kadar volatile matter yang ada pada tepung biji nangka.

Kadar volatile matter tergantung waktu pengarangan dan temperatur pengarangan. Kadar volatile matter akan turun presentasenya jika waktu pengarangannya diperlama. Selain itu jenis perekat yang digunakan juga mempengaruhi kadar volatile matter. Kadar volatile matter yang tinggi pada briket akan menimbulkan asap yang lebih banyak pada saat briket dinyalakan (Isa Lukum dkk, 2012). 


\section{Pengujian Nilai Kalor}

Hasil pengujian nilai kalor ditampilkan pada grafik di bawah ini.

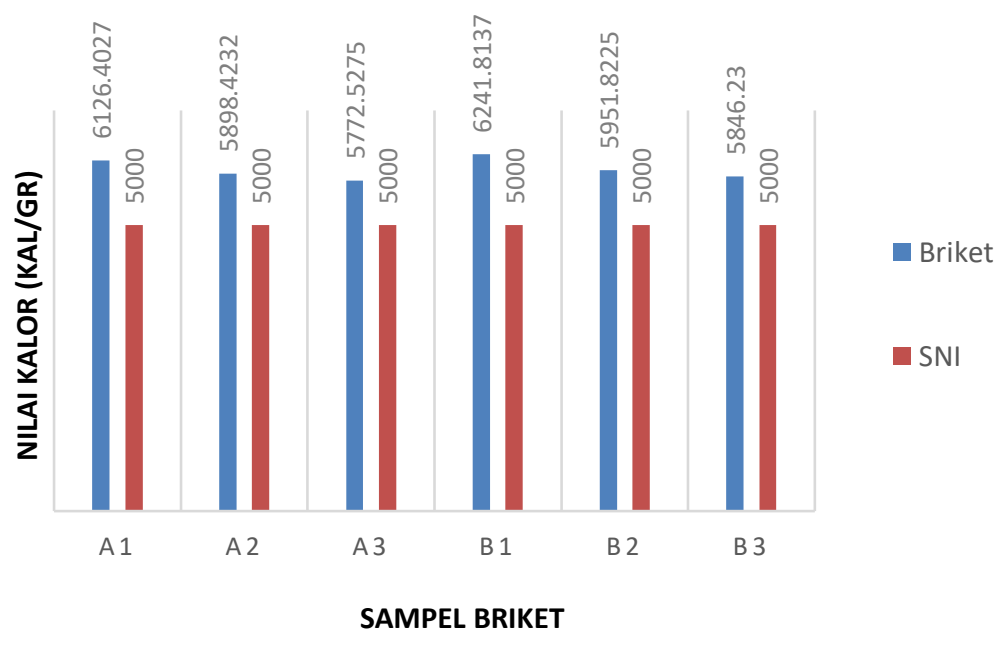

Gambar 4. Grafik nilai kalor

Berdasarkan Tabel 2 dan Gambar 4, briket dengan kode sampel A1 memiliki nilai kalor sebesar $6126,4027 \mathrm{kal} / \mathrm{gr}$, A2 memiliki kadar nilai kalor sebesar $5898,4232 \mathrm{kal} / \mathrm{gr}$, A3 memiliki nilai kalor sebesar 5772,5275 kal/gr, B1 memiliki nilai kalor sebesar 6241,8137 kal/gr, B2 memiliki nilai kalor sebesar 5951,8225 kal/gr, dan B3 memiliki nilai kalor sebesar 5846,2300 kal/gr.

Briket dengan nilai kalor terendah yaitu briket $A 3$ dengan nilai kalor sebesar $5772,5275 \mathrm{kal} / \mathrm{gr}$ dan briket dengan nilai kalor tertinggi yaitu briket B1 dengan nilai kalor sebesar $6241,8137 \mathrm{kal} / \mathrm{gr}$. Dari keenam briket tersebut seluruhnya memenuhi standar nilai kalor SNI 01-6235-2000 tentang mutu briket arang kayu dengan nilai kalor minimal $5000 \mathrm{kal} / \mathrm{gr}$. Semakin tinggi nilai kalor maka semakin baik kualitas briket yang dihasilkan.

Pada grafik memperlihatkan semakin tinggi tekanan pencetakan briket maka nilai kalor akan semakin tinggi. Hasil ini sesuai dengan penelitian Yenni Darvina dan Nur Asma (2011) pada penelitian tersebut dilakukan variasti tekanan pencetakan briket, dari hasil penelitian menunjukkan semakin besar tekanan pencetakan briket maka nilai kalor akan semakin tinggi. Tekanan pencetakan yang lebih tinggi akan membuat kadar air briket lebih rendah. Kadar air yang rendah akan membuat nilai kalor lebih tinggi.

Pada grafik memperlihatkan semakin banyak komposisi perekat maka nilai kalor akan semakin rendah. Hasil ini sesuai dengan penelitian Aquino Ghandi (2009) pada penelitian tersebut dilakukan variasi komposisi perekat briket, dari hasil penelitian menunjukkan semakin banyak komposisi perekat maka nilai kalor akan semakin rendah. Hal ini mungkin disebabkan perekat yang banyak mengandung air sehingga proses pembakaran kurang optimal, hal ini dibuktikan dari hasil uji kadar air yang menunjukkan semakin banyak perekat maka kadar air pada briket semakin tinggi. 


\section{KESIMPULAN}

Adapun kesimpulan yang diperoleh dari penelitian ini adalah sebagai berikut:

1. Karakteristik briket limbah tongkol jagung masing-masing briket yaitu briket A1 memiliki kadar air sebesar 7,6643\%, kadar abu 6,6538\%, kadar volatile matter $18,1494 \%$ dan nilai kalor 6126,4027 . Briket A2 memiliki kadar air sebesar $9,8159 \%$, kadar abu 6,4323\%, kadar volatile matter $18,7370 \%$ dan nilai kalor $5898,4232 \mathrm{kal} / \mathrm{gr}$. Briket A3 memiliki kadar air sebesar 12,0595\%, kadar abu $6,2405 \%$, kadar volatile matter $20,3581 \%$ dan nilai kalor $5772,5275 \mathrm{kal} / \mathrm{gr}$. Briket B1 memiliki kadar air sebesar 7,0073\%, kadar abu 6,8876\%, kadar volatile matter 17,8983\% dan nilai kalor $6241,8137 \mathrm{kal} / \mathrm{gr}$. Briket B2 memiliki kadar air sebesar 9,1915\%, kadar abu 6,7317\%, kadar volatile matter $18,4807 \%$ dan nilai kalor 5951,8225 kal/gr. Briket B3 memiliki kadar air sebesar 11,5085\%, kadar abu 6,4933\%, kadar volatile matter 20,2564\% dan nilai kalor 5846,2300 kal/gr.

2. Dari hasil perbandingan keenam sampel briket dapat diketahui bahwa briket dengan karakteristik terbaik adalah briket dengan kode sampel B1 dengan nilai kadar air sebesar 7,0073\%, kadar abu 6,8876\%, kadar volatile matter $17,8983 \%$ dan nilai kalor $6241,8137 \mathrm{kal} / \mathrm{gr}$. Namun secara keseluruhan briket tersebut belum memenuhi standar SNI 01-6235-2000 tentang mutu briket arang kayu. Dikarenakan kadar volatile matter briket tersebut melebihi batas maksimal yang telah ditentukan yaitu maksimal sebesar $15 \%$. 


\section{DAFTAR PUSTAKA}

Darvina, Yenni dan Nur Asma. 2011. Upaya Peningkatan Kualitas Briket dari Arang Cangkang dan Tandan Kosong Kelapa Sawit (TKKS) Melalui Variasi Tekanan Pengepresean. Penelitian Dana Jurusan. FMIPA : Jurusan Fisika. Universitas Negeri Padang. Padang.

Faizal, Muhammad dkk. 2014. Pengaruh Komposisi Arang dan Perekat Terhadap Kualitas Biobriket Dari Kayu Karet. Teknik Kimia No. 2 Vol. 20. Fakultas Teknik:Jurusan Teknik Kimia. Universitas Sriwijaya. Palembang.

Ghandi, Aquino. 2009. Pengaruh Variasi Jumlah Campuran Perekat Terhadap Karakteristik Briket Arang Tongkol Jagung. Skripsi. Fakultas Teknik Universitas Negeri Semarang. Semarang.

Hendra dan Darmawan. 2000. Pengaruh Bahan Baku, Jenis Perekat dan Tekanan Kempa Terhadap Kualitas Briket Arang. Puslitbang Hasil Hutan. Bogor.

Isa, I., Lukum, dkk. 2012. Laporan Penelitian Pengembangan Program Studi Dana PNPB Tahun Anggaran 2012. Universitas Negeri Gorontalo. Gorontalo.

Koswara, J. 1991. Budidaya Jagung. Jurusan Budidaya Pertanian, Fakultas Pertanian, Institut Pertanian Bogor, Bogor.

Lachke, A. 2002. Biofuel from D-Xylose The Second Most Abundant Sugar. India: Biochemical Science of Chemical Laboratory.

Maryono, Sudding dan Rahmawati. 2013. Pembuatan dan Analisis Mutur Briket Arang Tempurung Kelapa Ditinjau Dari Kadar Kanji. Jurnal Chemical Vol. 14 No. 1. FMIPA Jurusan Kimia. Universitas Negeri Makassar. Makassar.

Sabitah, A'yan. 2015._._. Skripsi. Teknik Mesin. Fakultas Teknik Universitas Lambung Mangkurat. Banjarbaru.

Sari, Ellyta dkk. 2015. Peningkatan Kualitas Biobriket Kulit Durian Dari Segi Campuran Biomassa, Bentuk Fisik, Kuat Tekan dan Lama Penyalaan. Simposium Nasional RAPI XIV. Fakultas Teknologi Industri. Universitas Bung Hatta. Padang

Singh dan Misra. 2005. Potensi Jarak Sebagai Tanaman Energi di Indonesia.

Syachri, T. N. 1983. Pengaruh Bahan Perekat Terhadap Briket Arang Kayu Tusam. Simposium Pengusahaan Hutan Pinus. Pusat Penelitian dan Pengembangan Hasil Hutan. Bogor.

Syaiful, Ahmad. 2010. "Pemanfaatan Sampah Kulit Durian dan Batubara Sebagai Sumber Energi Alternatif Biocoal". Thesis. Universitas Gadjah Mada. Yogyakarta.

Widarto. 1995. Membuat Bioarang Dari Kotoran Lembu. Yogyakarta : Sanisius.

Yunus, M. 2015. Karakteristik Thermal Briket Arang Limbah Serbuk Kayu Sengon dengan Variasi Tekanan. Skripsi. Fakultas Teknik : Jurusan Teknik Mesin. Universitas Jember. Jember 